\title{
Pengelolaan Administrasi dan Pencatatan Akuntansi Bagi Usaha Mikro Kecil Menengah
}

\author{
Sahmin Noholo ${ }^{1}$, Amir Lukum², \\ ${ }^{1,2}$ Jurusan Akuntansi, Fakultas Ekonomi, Universitas Negeri Gorontalo, Jl. Jend. Sudirman No. 6 \\ Kota Gorontalo, Gorontalo 96128, Indonesia \\ E-mail: $\underline{\text { sahmin.noholo@ung.ac.id }}{ }^{1}, \underline{\text { amirlukum@ung.ac.id }}^{2}$
}

Article History:
Received: 02-11-2021
Revised: 06-11-2021
Accepted: 07-11-2021

Keywords: Pengelolaan

Adminstrasi Keuangan,

Pencatatan Akuntansi, UMKM

\begin{abstract}
:
Tujuan pengabdian ini adalah melatih dan mendampingi para pelaku Usaha Mikro Kecil Menengah (UMKM) di Desa Botubarani Kecamatan Kecamatan Kabila Bone Kabupaten Bone Bolango dalam mengelola administrasi keuangan dan pencatatan akuntansi yang baik dan benar untuk kelangsungan usaha. Kegiatan ini dilakukan melalui pelatihan dan pendampingan yang diikuti oleh para pelaku UMKM di Desa Botubarani Kecamatan Kecamatan Kabila Bone Kabupaten Bone Bolango yang berjumlah 30 orang. Materi pelatihan meliputi pentingnya pengelolaan administrasi keuangan bagi usaha mikro, materi pengelolaan keuangan, dan pencatatan akuntansi yang baik dan benar. Setelah diberikan materi kemudian dilakukan pendampingan kepada peserta dalam menyusun perencanaan penganggaran dan pencatatan keuangan sederhana berdasarkan format yang diberikan oleh pemateri dengan menggunakan data masing-masing usaha.
\end{abstract}

\section{Pendahuluan}

Desa Botubarani merupakan desa yang terdapat di Kabupaten Bone Bolango yang merupakan salah satu destinasi wisata di Provinsi Gorontalo karena di desa ini terdapat obyek wisata yang terkenal yaitu Wisata Hiu Paus. Dengan adanya obyek wisata ini maka akan berdampak pada perekonomian masyarakat sekitar, yaitu dengan tumbuhnya usaha-usaha kecil di desa tersebut.

Namun demikian, banyaknya usaha-usaha kecil yang tumbuh di Desa Botubarani tidak dibarengi dengan manajemen usaha yang baik, yang salah satunya adalah bagaimana mengelola administrasi dan pencatatan akuntansi. Meskipun jenis usaha yang sedang dikelola masih pada tahap skala mikro dan kecil dengan proses yang lebih mudah dan sederhana, namun sebagai seorang wirausaha tidak ada salahnya jika harus merapikan administrasi dan pencatatan akuntansi yang baik sejak dari awal memulai usaha. Dengan administrasi dan pencatatan akuntansi yang lebih baik, maka para pelaku usaha kecil menengah akan menjadi lebih terbiasa dalam mempermudah untuk mengontrol arus keuangan usaha.

Menurut Riyanto (2013:11) pengelolaan administrasi dan pencatatan akuntansi adalah keseluruhan aktivitas usaha yang berhubungan dengan mendapatkan dana yang diperlukan dengan biaya yang minimal dan syarat syarat yang paling menguntungkan beserta usaha untuk menggunakan dana tersebut seefisien mungkin. Sedangkan Menurut Sartono (2015:7) pencatatan akuntansi adalah aktivitas operasional bisnis yang bertanggung jawab untuk mendapatkan dan menggunakan dana yang diperlukan untuk kegiatan operasional yang efektif 
dan efisien.

Dengan demikian maka pengelolaan administrasi dan pencatatan akuntansi merupakan cara tentang bagaimana dalam mengelola keuangan agar bisa mendapatkan keuntungan dan untuk penggunaan terhadap sumber modal sebagai upaya untuk pengembangan usaha.

Banyak diantara para pelaku usaha kecil yang beranggapan bahwa administrasi dan pencatatan akuntansi akan dapat berjalan dengan sendirinya, bersamaan dengan berjalannya usaha sampai mampu berkembang pesat. Mereka mengira bahwa jika usaha sudah berjalan dengan normal, maka keuangan usaha juga akan dengan sendirinya ikut membaik. Memang tidak bisa disangkal lagi jika penjualan dan keuntungannya merupakan sumber terbesar dari kas usaha. Namun usaha juga tidak semata-mata tentang bagaimana dalam mendapatkan uang yang banyak, akan tetapi juga tentang bagaimana cara kita dalam mengendalikan dan menggunakannya dengan lebih efektif dan efisien.

Berangkat dari situasi tersebut maka akan dilaksanakan pengabdian pada masyarakat di Desa Botubarani bagi para pelaku usaha kecil menengah.

\section{Metode}

1) Persiapan. Pada tahapan ini yang dilakukan yaitu a) Survei Lokasi; b) Pemantapan dan penentuan lokasi dan sasaran, penyusunan bahan atau materi sosialisasi serta penunjang lainnya serta penunjangan lainnya seperti surat menyurat, spanduk, dafat hadir, konsumsi, transportasi dan lain-lain.

2) Pelaksanaan. Pelaksanaan pelatihan dilakukan dengan melibatkan peserta secara langsung dengan memberikan materi serta mengulangi kembali materi yang diberikan kepada peserta untuk mengecek apakah peserta benar sudah memahami terkait dengan pelatihan yang diberikan oleh tim pengabdian. pelatihan pengelolaan keuangan usaha dimaksudkan agar para pelaku usaha dapat melakukan pencatatan yang benar dan juga mampu memprediksi perkembangan usaha dikemudian hari.

3) Rencana Keberlanjutan Program. Kegiatan dilaksanakan di Desa Batubarani, Kecamatan Kabila Bone, Kabupaten Bone Bolango. Tim pengabdian menyiapkan laporan mengenai pelaksanaan pelatihan yang dilaksanakan disertai dengan dokumentasi yang berkaitan dengan pelaksanaan pelatihan pada para pelaku usaha kecil menengah di Desa Botubarani.

\section{Hasil}

Kegiatan ini dimulai dengan koordinasi dengan mitra kelompok sasaran yakni para pelaku UMKM dan Kepala Desa di Desa Botubarani di Kecamatan Kabila Bone Kabupaten Bone Bolango. Dari hasil koordinasi dengan mitra, maka tim pengabdian menentukan peserta dalam kegiatan pengabdian ini yaitu para pelaku UMKM yang berada di Desa Botubarani. Adapun tempat pelaksanaan program pengabdian pada masyarakat ini dilaksanakan bertempat di Balai Desa Botubarani Kecamatan Kabila Bone Kabupaten Bone Bolango.

Kegiatan diawali dengan pembukaan acara yang dibuka secara resmi oleh Kepada Desa Botubarani. Untuk materi pertama adalah penjelasan tentang "Pentingnya Melakukan Pengeloaan Keuangan" selama 60 menit yang disampaikan oleh Bapak Sahmin Noholo, SE., MM. Setelah pemberian materi tersebut, masuk pada materi yang kedua adalah "Pengelolaan Administrasi Keuangan Usaha Mikro" yang disampaikan oleh Bapak Amir Lukum, S.Pd., MSA selama kurang lebih 2,5 jam. Dalam materi ini peserta diperkenalkan dengan bagaimana 
melakukan perencanaan usaha, pelaksanaan usaha, sampai dengan pencatatan yang diperlukan dalam mengelola usaha yang sederhana dan cepat dimengerti oleh para peserta.

Masuk pada materi yang ketiga yaitu tentang "pencatatan akuntansi untuk UMKM" yang disampaikan oleh Bapak Surya Ahmad, SE., M.SI selama kurang lebih 2,5 jam. Pada materi ini peserta lebih dikuatkan lagi materi terkait dengan pencatatan akuntansi yang sederhana dalam proses pengelolaan administrasi keuangan UMKM. Setelah memberikan penjelasan kepada para peserta kemudian peserta diberikan satu contoh kasus dalam melakukaan pengelolaan mulai dari merancang anggaran usaha sampai dengan pencatatan akuntansi bagi UMKM. Hal ini bertujuan agar peserta dilatih dan dapat memahami bagaimana dapat memulai suatu pengelolaan usaha yang baik dan benar. Setelah diberikan contoh kasus, kemudian peserta diberikan kasus untuk coba dikerjakan berdasarkan latar belakang usahanya masing-masing selama kurang lebih 3 jam. Setelahnya dilakukan penilaian apakah pekerjaan tersebut telah dilaksanakan dengan benar. Dari hasil pelatihan, akhirnya para peserta mampu dengan sendirinya mekakukan pengelolaan administrasi keuangan dan pencatatan akuntansi secara sederhana bagi usaha masing-masing dari peserta.

\section{Diskusi}

Terkadang mengelola keuangan dalam sebuah usaha sangat memusingkan. Tetapi ini adalah hal yang penting dalam usaha. Karena keadaan keuangan tersebut merupakan tolak ukur apakah usaha anda untung atau rugi. Keuangan merupakan jantung bagi setiap usaha. Karena setiap pergerakan dalam bisnis selalu ditinjau dari segi finansial. Administrasi keuangan sangat menentukan langkah ke depan yang harus diambil oleh pelaku UMKM. Oleh karena itu penting untuk mengelola keuangan dengan baik dan benar sehingga para pelaku usaha dapat mengendalikan keuangan usahanya.

Dalam mengelola keuangan bukan hanya sekedar melakukan manajemen uang kas tetapi bagaimana dalam mengelola administrasi keuangan dan bagaimana pencatatan akuntansinya merupakan bagaimana cara Anda mengelola kekayaan agar dapat menghasilkan keuntungan dan memanfaatkan sumber-sumber modal agar dapat membiayai usaha Anda. Meskipun terlihat sederhana, seorang pengusaha kecil serta menengah pun perlu menerapkan prinsip manajemen dalam mengelola keuangan usaha tersebut.

Untuk mengefektifkan berbagai fungsi dalam pengelolaan keuangan maka tugas administrasi yang perlu dilaksanakan. Manajmen tidak dapat menyiapkan perencanaan tanpa adanya data yang akurat. Kegiatan adaministarasi yang perlu dilaksanakan perusahaan antara lain:

a. Administrasi piutang, piutang adalah kekayaan perusahaan yang di dalam laporan neraca diletakan pada sisi asset atau aktiva. Administrasi piutang merupakan catatan yang penting. Catatan yang benar dan terkini sebagai informasi internal dan eksternal. Dalam kondisi eksternal piutang dapat dijadikan agunan kepada pemberi pinjaman untuk mengatasi keuangan jangka pendek. Manfaat bagi informasi internal adalah untuk perencanaan dan evaluasi/pengendalian.

b. Administrasi Hutang, hutang merupakan kewajiban perusahaan kepada pihak eksternal. Pada neraca akun hutang diletakkan pada sisi passive atau liability. Pencatatan hutang perusahaan sama pentingnya dengan piutang. Laporan tentang posisi hutang akan member peringatan kepada pelaku usaha untuk melakukan berbagai langkah antisipasi. 
c. Administrasi persediaan, persediaanmerupakan kekayaan perusahaan. Dalam neraca akun persediaan diletakkan pada sisi aktiva di bawah akun piutang. Persediaan memiliki peran yang strategic baik usaha yang bergerak di bidng perdagangan maupun manufaktur. Administrasi yang dilakukan secara tepat waktu sangat membantu pemilik usaha meng ambil keputusan kapan harus membeli kembali atau menjaga agat tidak kehabisan persediaan.

d. Administrasi asset tetap, asset tetapmerupakan kekayaan perusahaan yang di dalam neraca diletakkan pada sisi asset di bawah persediaan. Aset tetap berpotensi menjadi modal dengan 4 catatan data tentang setiap asset yang dimiliki prusahaan tercatat dengan tertib dalam administrasi asset. Pencatatan atas asset tetap berfungsi untuk menunjukkan kapan barang tersebut dibeli kemudian digunakan untuk menentukan tingkat penyusutan dan mulai berlakunya serta waktu berakhirnya.

e. Administrasi Kas, uang kas merupakan kekayaan perusahaan yang di dalam neraca diletakkan pada sisi asset dan dtempatkan paling atas. Jumlah kas lazimnya tidak besar dan ketersediaanya secukupnya untuk mendukung kegiatan perasional sehari-hari. Uag tunai di dalam kas perlu dijaga jumlah maksimalnya yakni sesbesar kebutuhan operasional. Pencatatan uang kas sangat berguna dalam memberikan informasi tentang berapa jumlah uang kas yang masuk dan yang keluar sehingga menjaga keseimbangan antara penerimaan dan pengeluaran.

f. Administrasi penggajian. Administrasi penggajian merupakan bagian dari manajmen personalia. Dalam system administrasi keuangan, administarsi penggajian masuk ke dalam kelompok biaya. Pencatatan tentang penggajian akan menginformasikan tentang jumlah biaya yang dibayarkan untuk upah pegawai. Administrasi pengajian juga sebagai dasar dalam perhitungan pajak. Manfaat lainnya untuk menjaga keseimbangan antara perubahanperubahan yang terjadi di lingkungan perusahaan sehubungan dengan kinerja karyawan.

g. Administrasi lainnya, administrasi surat masuk, surat keluar, pencatatan tentang berbagai kebijakan perusahaan, administrasi sewa-menyewa asset, kerjasama serta kegiatan langsung yang dilakukan oleh perusahaan. Pelaku usaha harus memperlakukan seluruh kegiatan administrasi dan pencatatan sebagai sumber informasi internal, oleh karena bersamaaan dengan peningkatan kegiatan usaha semakin diperlukan kolaborasi dengan pihak eksternal lainnya. Sedangkan pihak eksternal akan percaya kepada kita jika berbagai informasi yang mereka perlukan bias segera diberikan.

Berdasarkan hal tersebut, program pengabdian pada masyarakat ini bertujuan untuk memberikan sebuah pemahaman dalam pengelolaan administrasi keuangan UMKM bagi pelaku usaha.

Selain itu program pengabdian pada masyarakat ini juga untuk meningkatkan keberdayaan masyarakat melalui peningkatan income perkapita dengan adanya sentuhan pada sektor usaha/ekonomi, peningkatan indeks pembangunan manusia mengingat sentuhan peningkatan pengetahuan dan keterampilan masyarakat terutama para pelaku UMKM di Desa Botubarani Kecamatan Kabila Bone Kabupaten Bone Bolango Provinsi Gorontalo pada aspek partisipasi.

Berdasarkan hasil capaian dalam program pengabdian pada masyarakat ini pelaksanaannya berhasil dimana dari pelatihan yang diberikan kepada peserta sebagian besar peserta dapat memahami dan mengusai materi yang telah diberikan sebesar $85 \%$. Hal ini dapat terlaksana dengan baik karena para peserta tidak hanya diberikan materi saja, namun juga diberikan suatu kasus untuk kemudian dipecahkan dan juga dibimbing oleh tim pengabdian 
sampai dengan mereka mampu melakukannya.

Dari hasil program pengabdian pada masyarakat ini berhasil mengubah pola pikir para peserta bagiamana pengelolaan keuangan usaha yang baik dan benar.

\section{Kesimpulan}

Berdasarkan hasil pengabdian pada masyarakat di Desa Botubarani Kecamatan Kabila Bone Kabupaten Bone Bolango, maka dapat ditarik kesimpulan yaitu, para peserta mampu memahami dan menerapkan pengelolaan administrasi keuangan usaha dalam skala mikro kecil dan menengah yang baik dan benar sehingga terjadi perubahan pola pikir para peserta.

Kegiatan pengabdian pada masyarakat sangat dibutuhkan oleh masyarakat sebagai proses transfer ilmu bagi masyarakat dan pembelajaran masyarakat sehingga tetap perlu dilakukan keberlanjutan agar pengetahuan yang diberikan kepada para pelaku UMKM di Desa Botubarani Kecamatan Kabila Bone Kabupaten Bone Bolango tidak hilang dan dapat ditingkatkan lagi pada tingkat yang lebih mahir.

Masyarakat pelaku UMKM yang telah menerima ilmu yang diberikan diharapkan dapat memaksimalkan ilmu tersebut, serta memotivasi anggota kelompok masyarakat untuk memanfaatkan organisasi BUMDES sebagai wadah untuk berkarya dan berkreasi sehingga mampu meningkatkan pendapatannya.

\section{Pengakuan/Acknowledgements}

Ucapan terima kasih yang tak terhingga tim penulis berikan kepada semua pihak yang telah berkontribusi atas terlaksananya kegiatan pengabdian ini. Terima kasih kepada Desa Botubarani, Kec Kabila Bone, Kab Bone Bolango yang telah memberikan izin bagi tim pengabdi melaksanakan kegiatan ini, terima kasih pula diucapkan kepada para pelaku UMKM yang telah mengikuti dan tetap semangat dalam kegiatan pengabdian ini. Kepada tim pengabdi yang telah bersama-sama mensukseskan kegiatan pengabdian ini.

\section{Daftar Referensi}

Riyanto, Bambang. 2013. Dasar-Dasar Pembelanjaan Perusahaan. Edisi Keempat. BPFEYogyakarta. Yogyakarta.

Agus, Sartono. 2015. ManajemenKeuangan:TeoridanAplikasi. EdisiKeempat. Yogyakarta: BPFE. 